\title{
ARAF Gene Mutation
}

National Cancer Institute

\section{Source}

National Cancer Institute. ARAF Gene Mutation. NCI Thesaurus. Code C147061.

A change in the nucleotide sequence of the ARAF gene. 